\title{
TRANSLATION AND METAPHYSICS: A CASE FOR FICTIONAL CHARACTERS
}

\author{
Italo Lins Lemos 1 \\ 1Universidade Federal de Santa Catarina, Florianópolis, Santa Catarina, Brasil
}

\begin{abstract}
If different translations of the same literary work have different syntaxes and semantics, how are they supposed to be about one and the same fictional character? In order to answer this question it's necessary to (a) know what fictional characters are and (b) present reference conditions for them. Relying on Amie Thomasson's (1999, 2003, 2007) and Saul Kripke's $(1980,2013)$ works I argue that fictional characters are abstract artifacts whose reference is fixed by the baptism performed by an author; and that the identity of a fictional character is preserved due to the maintenance of the same chain of reference. Finally, I show how translators maintain the chain of reference initiated by the author of a given work and how consequently a fictional character remains the same abstract artifact throughout different translations.

Keywords: Fictional Characters; Reference Conditions; Abstract Artifacts
\end{abstract}

\section{Introduction ${ }^{1}$}

Would it be plausible to say that a given work of fiction and its translations are about one and the same fictional character? Let's take Franz Kafka's The Metamorphosis as an example. This novella was first written in German (Die Verwandlung) and published in 1915. In the very first passage of the story, the narrator tells

${ }^{1}$ I'd like to thank Amie Thomasson, Jaimir Conte, Takaaki Matsui and the reviewers for their helpful suggestions. 
us: "Als Gregor Samsa eines Morgens aus unruhigen Träumen erwachte, fand er sich in seinem Bett $\mathrm{zu}$ einem ungeheuren Ungeziefer verwandelt." (Kafka (a), 5).

Fortunately, for those who don't know how to read in German including myself - this classic novella has been translated to several other languages, such as English and Brazilian Portuguese. David Wyllie translated the previous passage as follows: "One morning, when Gregor Samsa woke from troubled dreams, he found himself transformed in his bed into a horrible vermin." (Kafka (d), 7). Susan Bernofsky, for instance, in a critical edition which was also published in English, translated the same passage somewhat differently: "When Gregor Samsa woke one morning from troubled dreams, he found himself transformed right there in his bed into some sort of monstrous insect." (Kafka (b), 3). And Modesto Carone chose the following words to express the passage above in Brazilian Portuguese: “Quando certa manhã Gregor Samsa acordou de sonhos intranquilos, encontrou-se em sua cama metamorfoseado num inseto monstruoso." (Kafka (c), 7)

Even an untrained eye would be able to notice the syntactic differences among those four passages. The words used in them are not the same: the German passage starts with "Als" and ends in "verwandelt", while the first English translation starts with "One" and ends in "vermin" and the second starts with "When" and ends in "insect"; and the Brazilian Portuguese version starts with "Quando" and ends in "monstruoso". Furthermore, the punctuation (therefore the rhythm of the reading and the style of the text) is also distinct: Wyllie's translation has two commas while all the other versions used commas only once.

${ }^{2}$ Even though it may seem an obvious statement, that an original text and its translations are composed of different words and phrases, it is important to notice that two texts written with the same words don't necessarily express one and the same work. Borges' Pierre Menard, Author of the Quixote, unlikely as it may be, makes us wonder about the conceptual possibility of two texts being written with the same syntax, i.e. ipsi literis, resulting in two different works if they are produced in different historical contexts. 
But the contrasts between these passages don't end here. Semantically, even though they express similar states of affairs, they do not mean the same things. The Brazilian Portuguese passage states that Samsa suffered a metamorphosis, while the English versions say he went through a transformation. The German word "ungeheuren" is closest in meaning to "monstrous" (it denotes something not only frightening and disgusting, but also unnatural) instead of "horrible", which was the choice made by Wyllies in the English translation.

The distinctions abound when we analyze the first sentences of Kafka's work. And it gets even thornier when we think about works with peculiar vocabularies such as James Joyce's Ulysses and Guimarães Rosa's The Devil to Pay in the Backlands. Then it seems fair to argue that we do not have the same literary experiences when we read different translations of the same work. But what happens to the fictional characters throughout these different translations? Do they remain the same? Or do we have for example four different Gregor Samsas originated from each of the passages quoted above?

In this paper I am going to argue that the one and the same fictional character is presented in the original work and in its corresponding translations. But in order to justify this thesis we have to (a) know what fictional characters are and (b) establish their reference conditions. We are going to notice that, along the lines presented by Amie Thomasson (1999, 2003, 2007) and Saul Kripke (1980, 2013), fictional characters are abstract artifacts whose reference is fixed by the baptism performed by an author; and that the ability to refer to the same fictional character is passed to and through the readers via a chain of reference. In sum, we intend to analyze the persistence of fictional characters throughout different translations from a metaphysical standpoint. 


\section{What is a fictional character?}

Fictional characters and stories are a relevant part of our everyday lives. Whether you are a literature student who has to write a paper on Vitangelo Moscarda's conflicts regarding personal identity in One, No One and One Hundred Thousand or if you just think it is entertaining to watch Daenerys Targaryen struggling for power in Game of Thrones, it is clear that we do spend some time discussing about, cheering for and even crying because of fictional characters. But what is a fictional character? Let's look at our literary practices and analyze two non-controversial statements:

(1) Gregor Samsa was created by Franz Kafka.

(2) Franz Kafka published The Metamorphosis in 1915.

Let's start with proposition (1). Authoring is an important concept in our literary practices because without human efforts there would be no such things as literary works and fictional characters $^{3}$. Unlike mountains and oceans, whose existence and creation don't depend on human intentions, fictional characters are attached to their author or authors, even though we might not know exactly who they were ${ }^{4}$.

As Amie Thomasson puts it,

One of the things we admire about certain authors is their ability to make up sympathetic, multidimensional characters

\footnotetext{
${ }^{3}$ It is important to note that this is not in properly in disagreement with what Roland Barthes (1977) said about the death of the author. Barthes' perspectives had to do with how the author's intentions shouldn't affect the meaning or interpretation of the text she or he authored, not that the creative acts of an author are not necessary for the story to be produced. If individuals were not necessary for the creation of a story, then fictional characters could've been conceived as natural kinds - which is quite counterintuitive.
}

${ }^{4}$ Which is the case of Homer, for example. 
rather than cardboard cut-outs, and at times we count our good luck that certain characters like Sherlock Holmes were created when, given a busier medical practice, Arthur Conan Doyle might never have created him. (Thomasson (c), 6)

So it is not controversial ${ }^{5}$ to state that Herman Melville authored Moby Dick and created Captain Ahab or that Dostoevsky wrote Crime and Punishment and created Raskolnikov; and that if they had dedicated their lives to some other activity than writing, we might not have been able to read stories about Ahab and Raskolnikov ${ }^{6}$. We take the process of authoring so seriously that if one person copies the work of another without citing or quoting him, the former may be accused of plagiarizing.

An author creates fictional characters through (a) an act of storytelling in (b) a public language in which they (c) receive a proper name or at least one description.

(a) The story needs to be expressed in a medium (written, filmed, performed or even transmitted orally) in order to be public, which means a fictional character is not something that exists "in the mind" of the author. If it existed in the mind of the author, as Roman Ingarden (1979) puts it, the fictional character would cease to exist as soon as the author's thought about the character vanishes. And that is surely not the case because we keep on thinking and talking about Gregor Samsa, even long after Kafka's death. (b) It has to be expressed in a public language (such as German, English, Brazilian Portuguese or a non-verbal language that might

\footnotetext{
${ }^{5}$ Terence Parsons (1980) and Edward Zalta (1983) have argued through the lenses of Alexius Meinong (1960) that fictional characters are not created, but selected from a realm of everlasting entities that subsist. But later in this section I'm going to give reasons for rejecting their account.

${ }^{6}$ There are cases in which the process of creation is debatable. Did Arthur Conan Doyle create the London of the stories or was he referring to the non-fictional city? Did Leon Tolstoy create a fictional character named Napoleon or was he referring to the historical figure who lost the Battle of Waterloo? Are they really fictional places and characters? (Cf. Parsons 1980 for a discussion on "surrogate entities").
} 
be understood by others) because fiction is a social institution with authors, readers and critics and the fictional characters come to existence due to our literary practices. And (c) we are only capable of directing our thoughts towards a fictional character and refer to it when it has been given either a proper name (such as "Gregor Samsa", "Captain Ahab" or "Raskolnikov") or a single or a cluster of descriptions (such as "the salesman who was transformed into an insect", "the captain of the whaling ship Pequod" or "the student who killed a corrupt pawnbroker with an axe", respectively).

Now let's go deeper into Amie Thomasson's theory and present it from a new point-of-view. If (1) is plausible, what is there for us to extract as a consequence?

(1) Gregor Samsa was created by Franz Kafka.

(1a) Therefore, Gregor Samsa is an artifact.

Artifacts are objects that are created intentionally by humans. We are surrounded by artifacts: chairs, tables, laptops, phones, books, etc. Actually, I am writing this paper using various artifacts at the same time and you are reading it using some of them as well whether you are reading it online using a computer or in a physical copy of Cadernos de Tradução, there is no way to avoid using artifacts in order to read it. We could even say that this paper itself is an artifact composed by me. In this sense, if Gregor Samsa was intentionally created by Franz Kafka - who was a human being - , then it is an artifact.

Even though Gregor Samsa may be similar to chairs, tables and laptops once all of them exemplify the property of being artifacts, fictional characters are not made of wood or aluminum and are not located in space and time. In the story, Samsa is said to be (or that he used to be) a human being, but he is not a person in the same sense in which Kafka was a person. Kafka was no kind of artifact. So fictional characters belong to a different category from that of concrete objects or individuals. Which category would that be? 
Thomasson $(1999,2003,2007)$ argues that the difference between fictional characters and other types of artifacts is that the former are abstract artifacts whereas the latter are concrete. We are not supposed to go to Baker Street in London in order to look for a detective made of flesh and bones called "Sherlock Holmes" because Sherlock Holmes isn't a person who can be found in space and time. Someone who goes to London in order to meet Sherlock Holmes (or to Rio de Janeiro to mourn on Brás Cubas' grave, etc.) is committing a category mistake and misunderstanding what it means for something to be a fictional character.

And unlike Platonic abstracta fictional characters are not necessary, timeless and changeless entities (Thomasson (c), 15). Fictional characters are contingent because if nobody had written a story about them, they would not have come into existence. They are temporal entities because they come into existence at a specific time when an author writes about them. And they are changeable because their properties usually don't remain the same throughout the same work, sequels or parodies. In this sense, fictional characters are similar to other abstract entities such as money, contracts and laws and this similarity shows that fictional characters are not unruly entities at all because they belong to metaphysical categories we are very familiar with.

Now it's time to analyze proposition (2). We know either through testimony or empirical research that Franz Kafka published The Metamorphosis in 1915. So unless a radical skeptic attempts to bring an evil genius to our discussion, (2) is surely an uncontroversial statement. If (2) is true, what can we infer from it?

(2) Kafka published The Metamorphosis in 1915.

(2a) Therefore, there was no such thing as Gregor Samsa before 1915 .

I've already mentioned that fictional characters are temporal entities and that they need to be expressed in a public language 
in order to come to existence. But there is still more to be said departing from that conclusion. If before 1915 there was no such thing as Gregor Samsa, then not only the theory I'm defending is different from Platonism, but it is also against some strains of Meinongianism. According to Terence Parsons (1980), the authors of fiction don't create fictional characters, but only discover or "select" a character from a pre-existing set of properties that are now individuated as fictional character. As Parsons himself puts it:

I have said that, in a popular sense, an author creates characters, but this too is hard to analyze. It does not mean, for example, that the author brings those characters into existence, for they do not exist. Nor does he or she make them objects, for they were objects before they appeared in stories. We might say, I suppose, that the author makes them fictional objects, and that they were not fictional before the creative act. We might even say that the author bestows on them fictional existence [...], as long as this is not confused with ordinary existence. (Parsons 188).

Parsons (idem, 17) argues that there are fictional characters, but they don't exist. This is due to the comprehension principle: for each object there is one and only one set of corresponding properties and for each set of properties there is one and only one corresponding object. Some of these objects exist (like chairs, tables and forks), some of them don't (like round squares and fictional characters). But given that we can entertain meaningful thoughts about such non-existing objects, they need to have some sort of watered-down mode of existence and that is why even though they don't exist, they are. I don't want to go in further details about why existence should be taken univocally and "there is" and "exists" actually mean the same thing. The point I would like to call attention to is that a theory that goes along with Parsons' claims is not consistent with our literary practices. First, it is not consistent with our practices because we do take authors to be essentially creative 
individuals. Second, as Thomasson ((c), 9) reminds us, some of the properties attributed to a fictional character or work of fiction depend on the time the story was written. If George Orwell had written Animal Farm before Stalin's time, this work could not have the property of being a satire of Stalinism. Third, there is the worry of anachronism: the words acquire meaning due to our practices and such atemporal realm of objects and sets of properties can't refer to practices that aren't yet even conceived of.

All in all, in the lines of Amie Thomasson's arguments, we should take fictional characters as abstract artifacts created at a specific time when an author or authors write about them in a public language. Now that we know what a fictional character is, let's carry on with our investigation and establish their reference conditions.

\section{Reference conditions for fictional characters}

Before delving into reference conditions I'd like to say a few things about identity conditions. Identity is a relation that every object maintains with itself. This relation can be divided in at least two types: qualitative identity and numerical identity. An object $\mathrm{A}$ is qualitatively identical to an object B if they share exactly the same properties. For example, if set 1 is composed of the properties \{circle, yellow\} and set 2 is composed of \{circle, yellow then we may affirm that set 1 is qualitatively identical to set 2 . In order words, it means set $1=$ set 2 . But in a lot of cases an object changes some of its properties through time but still remains numerically the same, i.e., it remains one and the same object. The most wellknown case is the problem of personal identity. Let's say that when I was a child a couple of decades ago I had, among other things, the properties \{being short, having long hair, ... \} and that right now I exemplify the properties \{being tall, having short hair, ... $\}$. Should I say that because a lot of my properties have changed through time I'm now a numerically different person? It doesn't seem plausible. I really am the same person despite all those changes. And this is 
exactly the problem I'm trying to solve here when it comes to the metaphysics of translation: is it possible for a fictional character to have different properties in different translations and still remain one and the same object?

But why am I more interested in discussing reference conditions than identity conditions? First, there is a huge debate on identity conditions for ordinary and fictional objects and I don't have the space that is required for tackling such a complex problem in this short paper ${ }^{7}$. Second, we already know what a fictional character is and how to identify it. We know that Sherlock Holmes, for example, is a fictional detective that was created by Arthur Conan Doyle and that is said to have helped the Scotland Yard and to have lived in 221B Baker Street in London. We know that according to The Metamorphosis Gregor Samsa became a terrible insect. Intuitively, we know that Sherlock Holmes is Sherlock Holmes and that it is not Gregor Samsa. All it takes for one to know these facts is to read the corresponding books or to have a reliable testimony that such things were said about those characters. Third, there is no need to go further than we already went on this topic because all we need to know is if it is the case that the proper names used by a translator pick exactly the same fictional characters presented in the original corresponding works. So all we need is a compelling theory of reference.

According to Saul Kripke (1980), a proper name is a rigid designator. Being a rigid designator means that a proper name refers to the same corresponding individual in all possible worlds. We might conceive a possible world in which Einstein didn't discover the theory of relativity and the individual picked by the proper name "Einstein" (or even by another name) would still be Einstein. So it's important to explain how we come to fix, borrow and maintain the reference of a proper name ${ }^{8}$.

${ }^{7}$ Cf. Thomasson 2007.

${ }^{8}$ Cf. Devitt \& Sterelny 1999. 
Kripke $^{9}((b), 96)$ says that an object "[...] may be named by ostension, or the reference of the name may be fixed by a description". Let's say I own a dachshund called "Dante". Dante is called "Dante" because right after I adopted him I pointed to him and asked the people around me "what if we called him 'Dante'?" and everyone said it sounded nice and agreed to use that name to refer to him. Now every time I use the name "Dante" the people who are acquainted with my dog know I'm referring to him. This is what Kripke called an act of dubbing or baptism. And to those who don't know Dante's name I may further say "it's my dog" and then they'll be a part of the community that uses that proper name to refer to that specific dog. Others who do or don't know the name of my dog may also refer to him by a description such as "the dog my philosopher friend owns". A disambiguation may be required in some occasions because there are other dogs (and even human beings) named "Dante" and maybe the individual I hypothesized about may have more than one philosopher friend or I may own more than one dog. But once the appropriate context is established, it's clear that the reference of a proper name is fixed either by ostension or description.

I claim that the same happens regarding a fictional character. When Franz Kafka thought about writing The Metamorphosis and decided the main character would be named "Gregor Samsa" he fixed a name to the abstract artifact he created. Some characters don't even need to have a name. "Frankenstein" from Mary Shelley's homonymous book is the name of Dr. Frankenstein instead of the creature he assembled in the laboratory. The creature has no name, but we can still refer to it by the description "Dr.

\footnotetext{
${ }^{9}$ Saul Kripke (1980) has put forward his theory of reference, but he has been noncommittal regarding the reference to fictional characters even in his Reference and Existence (2013). My approach to similar to Thomasson's (1999), but here I don't rely on the reference to physical entities in order to establish the reference to abstract artifacts.
} 
Frankenstein's creature" ${ }^{10}$. So there is no need to give a special account for reference fixing of fictional proper names.

But reference fixing is not enough. It's necessary that other people refer to the same individual using the same name. Kripke ((b), 96) says: "When the name is 'passed from link to link', the receiver of the name must, I think, intend when he learns it to use it with the same reference as the man from whom he heard it". In the case of the proper name "Dante" attributed to my dog, any speaker needs to learn from me or from someone that heard from me (or from someone who heard from someone who heard from me, etc.) that that name is supposed to be used to refer to my dog. Kripke ((b), 93) also says that "[...] what is true is that it's in virtue of our connection with other speakers in the community, going back to the referent himself, that we refer to a certain man", which means the reference of that name is borrowed from speakers who ultimately learned that name from me (who initially dubbed or baptized the dog) and created a chain of reference that is passed along to other speakers. The reference is maintained as long as the speakers preserve the use of that name that is linked to the so-called act of baptism of an object or individual.

Once again, I claim that this process also occurs in fiction. Franz Kafka named the main character of The Metamorphosis "Gregor Samsa" and anyone who read the book is now a part of the community that uses that proper name to refer to that fictional character created by Kafka. Even those who have never read The Metamorphosis may use the name "Gregor Samsa" to refer to the same individual as long as they have heard that name from a reliable source (a professor or even a Wikipedia page) and the use of that name is linked to the dubbing or baptism performed by Kafka.

In the introduction of this paper I argued that an original work and its corresponding translations are syntactically and semantically

\footnotetext{
${ }^{10}$ Some may refer to Dr. Frankenstein's creature by the name "Frankenstein". This could be seen as an interesting case of reference shifting or as an inadequate use of that proper name ( $C f$. Evans 1982).
}

Cad. Trad., Florianópolis, v. 40, n⿳ 1, p. 110-126, jan-abr, 2020. 
different for many reasons. First, because different languages have different syntaxes. Second, because translating is an act of choosing which words should be applied; and different translators usually choose words that don't have exactly the same meaning in order to translate the same sentences from the original work. Third, we may even make a thought experiment and think about the possibility of a translator committing a mistake that goes unnoticed by the editors. Let's suppose Kafka wrote that Samsa's eyes were blue and Modesto Carone translated "blue" as "vermelho" ("red") by mistake. Would that be enough to destroy the identity of a fictional character?

The answer is "no". We individuate a fictional character through a set of descriptions or a proper name that is coined through a dubbing or baptism. Once the baptism happens, all we need to do is discover where the chain of reference started, i.e., from where we learned how to use the name is question. In order words, all it requires is that the translator refers back to the same character created by the author whose work he's translating. And that's exactly what the translator does.

When David Wyllie and Modesto Carone translated Die Verwandlung from German to English and Brazilian Portuguese respectively ${ }^{11}$, they were maintaining the same chain of reference that Kafka started when he wrote that work. Both Wyllie and Carone were acquainted with Kafka's work and they translated Die Verwandlung knowing that it was written by Kafka and that what they were doing was a translation instead of writing a new novel from scratch. Gregor Samsa is still called "Gregor Samsa" in these translations and even if it was called by another proper name it would still refer to the same character because "Gregor

${ }^{11}$ Let's say a translator A translated Crime and Punishment from Russian to English and then a translator B translated the work from English to Brazilian Portuguese. The Brazilian Portuguese version would still preserve the numerical identity of Raskolnikov because it maintained the chain of reference established by Dostoevsky and translator A.

Cad. Trad., Florianópolis, v. 40, n⿳ 1, p. 110-126, jan-abr, 2020. 
Samsa" is a rigid designator ${ }^{12}$. The same chain of reference is maintained, so the same fictional character is presented in all those translations.

Even in the thought experiment in which the translator committed a mistake about the color of Gregor Samsa's eyes, the translation would have said something false about the one and the same character ${ }^{13}$. Even it wasn't a mistake, but an adaptation (maybe because it would sound better for the Brazilian readers), the same reasoning would follow: the translation would still be adapting some properties that are said to be attributed to the same Gregor Samsa that was created by Kafka. And that is precisely the problem that concerned us here and that now is hopefully untangled.

\section{Concluding remarks}

Fictional characters are abstract artifacts created by an author when he or she tells a story in a public language and they receive a proper name or a single or a set of descriptions. When the author or authors baptize their character, they create a chain of reference that is passed along to and through the readers that then become acquainted with that proper name or descriptions. If the translator maintains the chain of reference that began with the author of the work in question, then all the translations of that story are about one and the same character - even if they attribute to it properties that were not established in the original work. In this sense, when we read The Metamorphosis or A Metamorfose we engage with a fictional character that is numerically identical to the one we find in Die Verwandlung, i.e., there is one and the Gregor Samsa in all these versions. I hope I have contributed to the Translation Studies

\footnotetext{
${ }^{12}$ For example, the fictional character Speedy Gonzales was named "Ligeirinho" in Brazilian Portuguese, but "Speedy Gonzales" and "Ligeirinho" both refer to Speedy Gonzales for the same reasons above.

${ }^{13}$ Truth in fiction is another subject that is complex for me to tackle in this paper. Cf. Lewis, 1978.
} 
by analyzing the reference and identity condition of fictional characters from a metaphysical standpoint.

\section{References}

Barthes, Roland. "The Death of the Author. In: Barthes, Roland”. Image/Music/ Text. Translation by Stephen Heath. New York: Hill and Wang, 1977, p. 142147.

Borges, Jorge Luis. "Pierre Menard, Autor del Quijote'. In. Borges, Jorge Luis. Obras Completas. Buenos Aires: Emecé Editores, vol. 4, 2005, p. 475-482.

Devitt, Michael; Sterelny, Kim. Language and Reality: An Introduction to the Philosophy of Language. Cambridge: MIT Press, 1999.

Dostoevsky, Fyodor. Crime and Punishment. Translation by Michael R. Katz. New York: Liveright Publishing Corporation, 2018.

Doyle, Arthur Conan. A Study in Scarlet. London: Penguin Books, 2011.

Evans, Gareth. The Varieties of Reference. London: Oxford University Press, 1982.

Ingarden, Roman. The Literary Work of Art: An Investigation of the Borderlines of Ontology, Logic and Theory of Language. Translation by George Grabowicz. Evanston: Northwestern University Press, 1979.

Kafka, Franz. Die Verwandlung. Saillon: Jean Meslier Verlag, 2018(a). 
Kafka, Franz. The Metamorphosis. Translation by Susan Bernofsky. London: W. W. Norton Company, 2015(b).

Kafka, Franz. A Metamorfose. Translation by Modesto Carone. São Paulo: Companhia das Letras, 2015(c).

Kafka, Franz. The Metamorphosis. Translation by David Wyllie. U.S.A: Classix Press, 2009(d).

Kripke, Saul. Reference and Existence. London: Oxford University Press, 2013(a).

Kripke, Saul. Naming and Necessity. Cambridge: Harvard University Press, 1980(b) .

Lewis, David. “Truth in Fiction”. In. American Philosophical Quarterly, [s.1], v. 15 , n. 1, 1978, p. 37-46.

Meinong, Alexius. "On the Theory of Objects". In: Meinong, Alexius. Realism and the Background of Phenomenology. Translation by Isaac Levi, D. B. Terrell, and Roderick M. Chisholm. Atascadero: Ridgeview, 1960.

Melville, Herman. Moby Dick. London: Laurel Press, 1987.

Parsons, Terence. Nonexistent Objects. New Haven: Yale University Press, 1980.

Pirandello, Luigi. Uno, Nessuno e Centomila. Firenze: Giunti, 1994.

Shelley, Mary. Frankenstein. London: Dover Publications, 1994.

Thomasson, Amie. Ordinary Objects. New York: Oxford University Press, 2007(a). 
Thomasson, Amie. "Fictional Characters and Literary Practices". British Journal of Aesthetics, [s.1], v. 43, n. 2, 2003(b), p. 138-57.

Thomasson, Amie. Fiction and Metaphysics. Cambridge: Cambridge University Press, 1999(c).

Zalta, Edward. Abstract Objects. The Netherlands: Reidel, 1983.

Recebido em: 08/08/2019

Aceito em: 15/11/2019

Publicado em janeiro de 2020

Italo Lins Lemos. E-mail: italolinslemos@hotmail.com.

ORCID: https://orcid.org/0000-0003-2402-9820. Bolsista CAPES PDSE (Edital n. 47/2017), Processo n. 88881.186885/2018-01. 